\title{
IVL Gene
}

National Cancer Institute

\section{Source}

National Cancer Institute. IVL Gene. NCI Thesaurus. Code C96451.

This gene plays a role in keratinization. 